\title{
Role of Political Instability in Trade Pattern and Economic Growth: A Case of Pakistan
}

\author{
Areeba Suleman \\ Areebakhan900@gmail.com \\ PhD Scholar, School of Business Management, College of Business, \\ Universitiy of Utara Malaysia
}

\author{
Faiza Khalid \\ Faizakhalid@ucp.edu.pk \\ UCP Business School, Faculty of Management \\ Studies
}

\author{
ljaz Hussain Bokhari \\ Bokhari.jjaz@gmail.com \\ School of Business Management, College of Business \\ Universiti of Utara Malaysia
}

\begin{abstract}
Economic growth is based on the foreign investments and international trade based on stable and consistent policies. Stable political and economic policies attract the foreign investments and international trade. Political instability affect the foreign investment and economic growth. The role political instability has been tested on the pattern of international trade and economic growth. The results shows that terms of trade insignificant while trade restriction indication a significant impact on economic growth. Trade patterns indicates a significant relationship with economic growth. The results indicates that political instability affect the relation of trade pattern and economic growth adversely as moderating factor. It has been observed that political instability is quite high in case of Pakistan. Since last ten years political system of Pakistan is improving after the revival of democratic system and trade with neighboring and developed countries is improving and a positive signals has been observed in economic growth of Pakistan

Keywords: Trade, Economic Growth, Poliitcal Instablity, Pakistan
\end{abstract}

\section{Introduction}

In developed countries the level of poverty is relatively low as compared to underdeveloped or developing countries, while the economic growth rate of developed economics is relatively high (Iniguez-Montiel, 2014). Furthermore, the previous study related to cross country indicates that developed economies achieve fast and continue growth in an economy (Lin, 2011). Recent literature documented that fast and continued economic growth has positive and significant relationship with Patterns of trade (Outreville, 2013). Imports of capital nature products like latest technology, machineries and knowledge and exports of final products leads towards the economic growth and economies achieve the comparative advantage of others (Shimbov, 2016).

However, production capacity of economies vary, development economies outsource most of its operations and productions to developing economies and achieve competitive advantage because developing economies have cheap labor while the developing economies like Pakistan unable to achieve fast and consist economic growth due to number of factors; import raw material, technology, knowledge, technical skills and the most important is supply of electricity (Macchion et.al, 2015). Pakistan industry faces high level of electricity shortfall, while adversely affect the productions, operations and ultimately leads to lower productions and exports (Hong, 2014). Electricity shortfall badly affect the textile sector of Pakistan, it has been observed that most of the industrial unit in

The current issue and full text archive of this journal is available at www.jraspublications.org/index.php/JRAS/issue/archive Journal of Research in Administrative Sciences (JRAS)

VIII(II), 10-15, ISSN: 2664-2433 textile sector closed and some of them moved from Pakistan to other countries due to electricity shortfall (Kessides, 2013).

While, remaining companies start their own plants for electricity generations (Ali, 2015). In addition to that, Khan (2014) describes that textile industry is main part of Pakistan in agriculture sector. Moreover, it is the foundation of Pakistani economy. Electricity is an important part of our economy and large part of electricity is involved in productivity and utilization processes in our economy (Ellabban et al, 2014). Over the past decades Pakistan has increase Gross Domestic Product (GDP) and high level of electricity production. The level of industrial production, economic growth and level of employment is badly affected due to electricity shortfall (Ahmed et al, 2013).

Electricity shortfall is the main reason to affect the Textile sector of Pakistan because large part of GDP (Gross Domestic Product) of Pakistan is significantly by textile industry, exports and employment (Ahmad \& Bashir, 2013). Textile industry has developed 1550 million kgs of yarn, 4368 million square meters of fabric related to weaving capacity and 4000 million square meters of fishing capacity (Essays, 2013).

Cotton is an important part of textile industry in terms of raw material. It is developed 3-million-hectare scale by $26 \%$ of agriculture. The huge portion of cotton $80 \%$ developing in Punjab and the rest of $20 \%$ is developing in Sindh. The GDP of Pakistan is 


\section{A. Suleman, F. Khalid, I. H. Bokhari}

$8 \%$ and employment is $17 \%$ and foreign exchange earnings are about to $54 \%$ (Javid \& Sharif, 2016). Cotton was banned due to some reasons related to trade. Recently, Pakistan has endorsed different types of trade but twist infection, food security and meal bugs are in process to endorse by Pakistan (Fader et al, 2013). Government of Pakistan has different projects related to cotton for improvement of textile sector and endorse different types of new cotton diversifications (Abdul Ghafoor, 2015).

Cotton is the main cash crop in china and useful commodity in different countries for agriculture provides benefit in terms of rural areas (Smyth, Kerr, \& Phillips, 2015). Moreover, cash generated from cotton crop utilization needs for farmer families and provides the raw material in terms of basic production for household markets as well as exports point of view (De Haas, 2017). At domestic level cotton is the main source to earn finance and provides benefits to farmers internationally (Cheru \& Modi, 2013).

Vietnam's cotton yarns is a basic import raw material in china and the value of import approximately $625^{\prime} 000$ tons in 201612017 , the value of exports in terms of accounting is $84 \%$ of Vietnam's total cotton yarns (Xinping, Clever, \& Wu, 2016). Pakistan should foot a bill of around $\$ 1.58$ billion for the import of 4.5 million parcels (170kg each) to overcome any issues between the generation and utilization of crude cotton. Cotton creation timed up at $15 \mathrm{~m}$ parcels in 2014-15 and $9.5 \mathrm{~m}$ bunches in 2015-16. It is relied upon to be around $10.54 \mathrm{~m}$ bundles in 2016-17. Pakistan was the third biggest crude cotton exporter, yet it has been a shipper throughout the previous two years. A year ago, Pakistan imported around $2.7 \mathrm{~m}$ bunches from India at a cost of \$800m (Rana, 2017).

Trade free Agreement

Trade free agreements facilitate the economies in boosting their trades among the neighbor countries based on the gravity model of International trade, by eliminating the barriers countries/ industries faced in trade (Kahouli \& Maktouf, 2015). According, to World Trade Organization (WTO) total number of regional trade agreements around the globe is around 700 in total (Wübbeke, 2013). In south-Asian region several countries decided and signed a number of trade free agreements among neighbor economies based on the trade patterns (Iapadre \& Tajoli, 2014). Pakistan sign several trade free agreements with neighbor countries including, India, Bangladesh, Sri-Lanka and China. Pakistan sign a number of trade free agreements with China because China has been biggest rapid growing country for so many years, now it is the second biggest country (Bergstrand \& Egger, 2007). China Pakistan Free Trade Agreement (CPFTA) on 24th November 2006, which came into effect in July 2007 (Ezeani, 2018). Free Trade Agreement is the main source to boost the relationship between countries and help to increase economic growth of the member countries (Baier \& Bergstrand, 2007) . Gray (2014) describes that comparative advantage is occurred due to Regional Trade Agreements (RTAs), in this way economic growth of countries increased due to benefits of excess resources/factors.

The trade of different products like cotton fabrics, other home textiles, bed-linen, leather related stuff, sports material, fruits and vegetable include many other commodities through Free Trade Agreement with china give best advantage as compared to other countries (Tiefenbrum, 2013). Furthermore, these products are comparatively high-growth products in any country of the world (Scott, 2008).

The initial purpose of this agreement is to provide bilateral trade and create large number of market entry to the commodities in terms of common basis (Baldwin \& Lopez-Gonzalez, 2015). According to Tariff Reduction Modalities (TRM), during first three years both countries decided to remove taxes almost 36 percent of the total tax applicable of Phase-I and that is finished in 2012. The second step of this agreement is not decided yet but in which included all taxes and better trade procedures will be made in near future and agreement on trade acceptance is still in process (Junaid \& Malik, 2017).

Early Harvest Program (EHP) is an agreement, in which the relationship between china and Pakistan is stronger and it is

\section{Volume VIII, Issue II, 2019, 10-15}

performed on January 1, 2006 (Kataria \& Naveed, 2014). This agreement was basically the initial step moving towards free trade sector, furthermore China and Pakistan provides a market entry on a large scale to each other on the products of important trade interests (Hussain \& Khan, 2017).

The China -Pakistan Economic Corridor (CPEC) is main source to provide facilities not only to Pakistan and china but also for the entire economy (Sial, 2014). The main aim to create this network for roads, railways and different energy projects, the main purpose for this network is linkup Pakistan's Gwadar port to the China's Xinjiang province, besides helping Pakistan in improving its supply side constraints (Brewster, 2017).

Objective of Study

The objective of this study will be:

- To investigate the impact of trade pattern (imports \& exports) of cotton on economic growth of Pakistan and china.

- To identify the moderating effects of electricity shortfall on economic growth of Pakistan and china.

- To explore the direct effect of electricity shortfall on economic growth of Pakistan and china.

- To explore the direct effect of electricity shortfall on Trade pattern (imports \& exports) of cotton.

\section{Significance of study}

- The significance of this study is to investigate the impact of imports and exports of cotton on economic growth catching up with the recently rapid technological advances in production.

- This study is helping to increase the economic growth of Pakistan by exporting cotton and china by importing cotton.

- This study also helps the farmers and to educate in proper manner with available facilities and it will explore new ways to improve our social; and natural resources as well for the cotton production at large scale.

\section{Literature Review Import and Export of Cotton}

The second largest share after United States which is 16.7 percent in Pakistan is China with 7.7 percent of share in export (Uprasen, 2016). The main export of Pakistan towards China is cotton and rice which is 75 percent of the total export of Pakistan to China (Lenzen et al, 2013). The most important thing is that export is increasing between these countries as in 2006 it was up to 358 million US dollar and in 2016 it increased to 968 million US dollar (Yeeles \& Akporiaye, 2016). China has become one of the largest importers of cotton Yam after Bangladesh. (Junaid \& Malik, 2017). There was downward trend of growth rates and imports were showing the negative whereas the export of cotton was showing strong trend of upwards (Leslie \& Stephen, 2016).

Pakistan should work to remove the hurdles which comes in the area where they are strong in exports which not only includes cotton yarn but also cotton fabrics and other products of cotton which are exporting to China (Islamx et al, 2013). An estimated percentage of export is $80 \%$ containing cotton in raw form and cotton yarn. (Noor, 2014). The positive impact in liberalization of trade and growth in economic internationally which leads towards favorable economic environment among exports in South Africa which has been proved by their study (Sofia Anwar, 2010).

The imports in 2016 decreased in different countries in which China's dropped up to $30 \%$ of cotton yarn which had worth of 960 million kgs amounting US $\$ 2,430$ million, whereas there is also noted that export of India also decreased up to $49 \%$ which is of 231 million KGs having worth of 560 million US dollar. In the same year there were total imports if 159 million KG which worth 400 million US dollar while in 2015 the import was of 593 million US dollar against 216 million KG. The average price of imports of cotton yarn is comparatively less than China India and Vietnam which was 2.14 US dollar and 2.51 in China, 2.40 in India and 2.55 from Vietnam (Times of Islamabad, 2016). 


\section{Role of Political Instability}

Political stability is a vital or considered as founding factor for the economic development and consistent growth of a country. While an unstable political system can hamper the industrial as well as economic growth. The theme of political instability was defined by Lipstel (1960) as "a country is considered as stable if it has been a liberal and consistent democracy or dictatorship for 25 years". However, modern school of thought documented political instability as "efficiency of government system and policy objectives".

Prior literature indicates that instable and volatile political system affect the economic growth. Political system affect the system in two ways firstly, it affect the private investment which affect the economic growth and secondly, it affect the purchasing capacity of people which affect the economic growth. Private investments from the multinational companies boost trade potential of any economy and ultimately boost it economic growth.

Due to political instability there is governments' constantly change their policies and come up with new decisions so, it is really hard for the risk averse agents/ investors to invest in political instable country. Investors more prefer to invest in a country with lower political instability or with stable economic environment even with lower returns (Alesina \& Perotti, 1996; Barro, 1991).

Inconsistency or consistent variation has been observed in economic growth of Pakistan since 1970. Pakistan's economy is facing aftershocks political instability after the war of 1971. War of 1971 affect the economic growth of Pakistan in terms of capital and human resources. Pakistan recover from the war of 1971 and enjoyed a sustainable growth till 1988 due to afghan war. Afghan war and due to consistent changes in governments affect the political and economic policies of Pakistan. Irrational and inconsistent policies affect the economic growth of Pakistan.

\section{Research Methodology}

The subject of study is Trade Pattern of cotton and economic growth with moderating role of electricity shortfall. This research follows the quantities technique to achieve the research objectives. Quantitative nature of data will be collected to achieve the research objectives of current study. To achieve the research objective current study 20 years data will be employed and next 20 years will be forecasted to test the relationship of trade patterns of cotton and economic growth data will be collected from Index Mundi and World Bank Indicator.

To test the effect of trade patterns on economic growth with mediating role of electricity shortfall, regression technique will be employed. To test the direction of relationship granger causality technique will be employed. All the assumptions of regression technique will be employed before the application of regression technique. Moreover, to test the granger causality technique, unit root test will be employed.

Table 1: Descriptive statistics

\begin{tabular}{llll}
\hline & Mean & $\begin{array}{l}\text { Std. } \\
\text { Deviation }\end{array}$ & $\mathrm{N}$ \\
\hline GDP & 4.93 & 2.39 & 67 \\
Political & 1.38 & 1.23 & 67 \\
Instability & & & \\
TOT & 2.19 & 3.21 & 67 \\
TR & .009 & .012 & 67 \\
\hline
\end{tabular}

In descriptive statistics presented in Table 1 (comparing means and SD's of GDP (Growth

Rate), Political instability, Term of trade and trade restrictions. In this table the values of political instability and trade restrictions is better, stable and consistent whereas the values of GDP and term of trade is volatile.

\begin{tabular}{lclll}
\multicolumn{5}{c}{ Table 2: Correlations Analysis } \\
\hline & GDP & $\begin{array}{c}\text { Political } \\
\text { Instability }\end{array}$ & TOT & TR \\
\hline GDP & 1 & & & \\
Political & .051 & 1 & & \\
Instability & & & & \\
TOT & .206 & -.148 & 1 & \\
TR & .397 & -.423 & .159 & 1 \\
$\mathrm{~N}$ & 67 & 67 & 67 & 67 \\
\hline
\end{tabular}

This table demonstrates the relationship between variable with significant and insignificant level. Therefore, the relation between the GDP and political instability sis $r=0.51$, shows weak positive and significant relationship between GDP and political instability as $\mathrm{P}$ value is less than 5\%. The relationship of political instability and term of trade is $\mathrm{r}=-0.148$ shows negative and insignificant relationship as $\mathrm{P}$ value is greater than 5\%. The relationship between term of trade and trade restrictions is $r=.0159$, shows that weak positive and insignificant relationship as $\mathrm{P}$ value is greater than 5\%.

Table 3: Model Summary

\begin{tabular}{|c|c|c|c|c|c|c|c|c|c|}
\hline \multirow[t]{2}{*}{ Model } & \multirow[t]{2}{*}{$\mathbf{R}$} & \multirow[t]{2}{*}{ R Square } & \multirow{2}{*}{$\begin{array}{l}\text { Adjusted R } \\
\text { Square }\end{array}$} & \multirow[t]{2}{*}{ Std. Error Est } & \multicolumn{4}{|c|}{ Change Statistics } & \multirow{2}{*}{$\begin{array}{l}\text { Durbin- } \\
\text { Watson }\end{array}$} \\
\hline & & & & & R Square Change & F Change & & ig. F Change & \\
\hline 1 & $.051^{\mathrm{a}}$ & .003 & -.013 & 2.41 & .003 & .171 & & .680 & \\
\hline 2 & $.494^{\mathrm{b}}$ & .244 & .208 & 2.13 & .241 & 10.037 & & .000 & 1.380 \\
\hline \multicolumn{5}{|c|}{$\begin{array}{l}\mathrm{R} \text { square value is about } .003 \text { which means that } 0.3 \% \text { variation is } \\
\text { GDP is explained by political instability and for GDP R- square } \\
\text { value is } .244 \text { which shows that } 24.4 \% \text { variation due to political } \\
\text { instability, term of trade and trade restrictions. The value of F- }\end{array}$} & $\begin{array}{l}\text { statistics shor } \\
\text { good fitted m } \\
\text { model accordi } \\
\text { erated Regression }\end{array}$ & $\begin{array}{l}\text { s that model is } \\
\text { del. While the } \\
\text { ng to F - statist }\end{array}$ & $\begin{array}{l}\text { GDP } \\
\text { mode } \\
\text { ics val }\end{array}$ & $\begin{array}{l}\text { with political i } \\
\text { trade restrictior } \\
\text { lue. }\end{array}$ & $\begin{array}{l}\text { ability is not } \\
\text { is good fitted }\end{array}$ \\
\hline \multirow{2}{*}{\multicolumn{3}{|c|}{ Model }} & Unstandard & ed Coefficients & $\begin{array}{c}\text { Standardized } \\
\text { Coefficients }\end{array}$ & $\mathbf{t}$ & Sig. & \multicolumn{2}{|c|}{ Collinearity Statistics } \\
\hline & & & B & Std. Error & Beta & & & Tolerance & VIF \\
\hline \multirow{3}{*}{1} & (Constant) & & 4.79 & .445 & & 10.77 & .000 & & \\
\hline & Political In & bility & .100 & .241 & .051 & 0.41 & 680 & 1.00 & 1.00 \\
\hline & (Constant) & & 3.01 & .561 & & 5.37 & .000 & & \\
\hline \multirow{3}{*}{2} & Political In & oility & .550 & .236 & .283 & 2.33 & .023 & .81 & 1.22 \\
\hline & TOT & & .127 & .083 & .170 & 1.52 & .132 & .97 & 1.03 \\
\hline & TR & & 3.19 & 25.64 & .489 & 4.02 & .000 & .81 & 1.23 \\
\hline
\end{tabular}

In model 1 the $\mathrm{P}$-value of $\left(b_{1}\right)$ is .680 shows insignificant relationship between GDP and political instability which is greater than 0.05 . In model 2 the $\mathrm{P}$ - value shows the significant results in terms of the relationship between GDP and political instability as a moderator variable. In model 2 the P-value of term of trade and trade restrictions is 0.132 and .000 shows insignificant relationship between GDP and term of trade and significant relationship between GDP and trade restrictions.

\section{Conclusion and Discussion}




\section{A. Suleman, F. Khalid, I. H. Bokhari}

International trade is considered a key factor in economic growth. Trade liberalization facilitate the economies to achieve high level of growth rate through international trade. Economies boost their international trade through trade free agreements and based on the gravity model. International trade bring foreign investments and prosperity to the economy. Political and economic stability effect the economic growth and trade patterns. Trade patterns is solely based on the political agreements and how countries are politically or economically associated with each other. Countries with political instable lose their trade with neighboring countries and other developed and developing countries which ultimately affect the economic growth.

The results affirms that trade patterns positively and significantly improve the economic conditions and growth. However, economy of Pakistan is facing the factor of political instability. Political instability affect the relationship of trade patterns and economic growth as moderating factor. Economy of Pakistan is suffering from irrational and unfavorable political and economic policies. Since 1970, Pakistan's economy is facing issues and challenges in terms of democratic political governments and due to instable economic policies.

Future research need to test this relationship on neighboring countries or developing countries like Pakistan. Government of Pakistan needs to focus on economic policies and these policies should be favorable to investors so foreign investment should inflow to Pakistan. Government should also focus trade policies to enhance the exports of Pakistan which ultimately increase the economic growth.

\section{References}

i. Abubakar, L. H. (2011). An evaluation of a company's resources and capabilities; achieving and sustaining competitive advantage in Nigerian firms. Journal of Management Research and Development, 2(1), 45-59.

ii. Adom, K. (2015). Recognizing the contribution of female entrepreneurs in economic development in subSaharan Africa: Some evidence from Ghana. Journal of Developmental Entrepreneurship, 20(1), 1-24.

iii. Ahmad, F., \& Bashir, T. (2013). Explanatory Power of Macroeconomic Variables as Determinants of NonPerforming Loans: Evidence form Pakistan. World Applied Sciences Journal, 22(2), 243-255.

iv. Ali, M., \& Faisal. (2010). Localization and Internationalization Case study: Pakistan (Local) vs. EU expansion opportunities and barriers for NATA Surgical International. sweden: Karlstad Business School.

v. Amadeo, K. (2018, 09). What Is Competitive Advantage? Three Strategies That Work. Retrieved from The Balance: https://www.thebalance.com/what-iscompetitive-advantage-3-strategies-that-work-3305828

vi. Baier, L. S., \& Bergstrand, H. J. (2007). Do free trade agreements actually increase members' international trade? Journal of international Economics, 71(1), 72-95.

vii. Baldwin, R., \& Lopez-Gonzalez, J. (2015). Supply-chain trade: A portrait of global patterns and several testable hypotheses. The World Economy, 38(11), 1682-1721.

viii. Beise, M., \& Rennings, K. (2005). Lead markets and regulation: a framework for analyzing the international diffusion of environmental innovations. Ecological economics, 52(1), 5-17.

ix. Bilal, R. A., Khan, A. A., \& Akoorie, M. E. (2016). Constraints to growth: a cross country analysis of Chinese, Indian and Pakistani SMEs. Chinese Management Studies, 10(2), 365-386.

x. Bose, K. T. (2016). Critical success factors of SME internationalization. Journal of Small Business Strategy, 26(2), 87-109.

xi. Buckley, J. P. (2016). The contribution of internalisation theory to international business: New realities and unanswered questions. Journal of World Business, 51(1), 74-82.

\section{Volume VIII, Issue II, 2019, 10-15}

xii. $\quad$ Burns, P. (2016). Entrepreneurship and small business. Palgrave Macmillan Limited.

xiii. Calabro, A., Torchia, M., Pukall, T., \& Mussolino. (2013). The influence of ownership structure and board strategic involvement on international sales: The moderating effect of family involvement. International Business Review, 22(3), 509-523.

xiv. Carr, C., \& Bateman, S. (2009). International strategy configurations of the world's top family firms. Management International Review, 49(6), 733-758.

xv. Chadwick, C., Super, F. J., \& Kwon, K. (2015). Resource orchestration in practice: CEO emphasis on SHRM, commitment-based HR systems, and firm performance. Strategic Management Journal, 36(3), 360-376.

xvi. Ciravegna, L., Majano, B. S., \& Zhan, G. (2014). The inception of internationalization of small and medium enterprises: The role of activeness and networks. Journal of Business Research, 67(6), 1081-1089.

xvii. De Haas, M. (2017). Measuring rural welfare in colonial Africa: did Uganda's smallholders thrive? The Economic History Review, 70(2), 605-631.

xviii. Dereli, D. D. (2015). Innovation management in global competition and competitive advantage. Procedia-Social and behavioral sciences, 195(1), 1365-1370.

xix. Dhanaraj, C., \& Beamish, W. P. (2003). A resourcebased approach to the study of export performance. Journal of small business management, 41(3), 242-261.

xx. Diamantopoulos, A., Siguaw, A. J., \& Cadogan, W. J. (2000). Export peformance: The impact of cross-country export market orientation. In American Marketing Association. American Marketing Association, 11(1), 174-177.

xxi. Dicken, P. (1998). Global shift: transforming the world economy. New York: Guilford. Retrieved from http://worldcat.org/isbn/1572303034

xxii. Dunning, H. J. (1997). The European internal market programme and inbound foreign direct investment. Journal of Common Market Studies, 35(2), 189-223.

xxiii. Ellabban, O., Abu-Rub, H., \& Blaabjerg, F. (2014). Renewable energy resources: Current status, future prospects and their enabling technology. Renewable and Sustainable Energy Reviews, 39(1), 748-764.

xxiv. Etemad, H. (2004). Internationalization of small and medium-sized enterprises: a grounded theoretical framework and an overview. Canadian Journal of Administrative Sciences/Revue Canadienne des Sciences de l'Administration, 21(1), 1-21.

xxv. Ezeani, E. (2018). Comparative advantage in deglobalisation: Brexit, America First and Africa's Continental Free Trade Area. Journal of International Trade Law and Policy, 17(1), 46-61.

xxvi. $\quad$ Fader, M., Gerten, D., Krause, M., \& Lucht, W. (2013). Spatial decoupling of agricultural production and consumption: quantifying dependences of countries on food imports due to domestic land and water constraints. Environmental Research Letters, 8(1), 1-15.

xxvii. Fayos Gardó, T., Calderón García, H., \& Mollá Desc. (2015). Internationalization of SME retailer: barriers and the role of public support organizations. International Journal of Retail \& Distribution Management, 43(2), 183-200.

xxviii. Felin, T., \& Foss, J. N. (2011). The endogenous origins of experience, routines, and organizational capabilities: the poverty of stimulus. Journal of Institutional Economics, 7(2), 231-256.

xxix. Fuerst, S., \& Zettinig, P. (2015). Knowledge creation dynamics within the international new venture. European Business Review, 27(2), 182-213. 
xxx. Gupta, M., \& George, F. J. (2016). Toward the development of a big data analytics capability. Information \& Management, 53(8), 1049-1064.

xxxi. Hayton, C. J., George, G., \& Zahra, A. S. (2002). National culture and entrepreneurship: A review of behavioral research. Entrepreneurship theory and practice, 26(4), 33-52.

xxxii. Helfat, E. C., \& Winter, G. S. (2011). Untangling dynamic and operational capabilities: Strategy for the (N) ever-changing world. Strategic management journal, 32(11), 1243-1250.

xxxiii. Helfat, E. C., \& Winter, G. S. (2011). Untangling dynamic and operational capabilities: Strategy for the (N) ever-changing world. Strategic management journal, 32(11), 1243-1250.

xxxiv. Hermano, V., \& Martín-Cruz, N. (2016). The role of top management involvement in firms performing projects: A dynamic capabilities approach. Journal of Business Research, 69(9), 3447-3458.

xxxv. Hong, J., Wang, C., \& Kafouros, M. (2015). The role of the state in explaining the internationalization of emerging market enterprises. British Journal of Management, 26(1), 45-62.

xxxvi. Iapadre, L. P., \& Tajoli, L. (2014). Emerging countries and trade regionalization. A network analysis. Journal of Policy Modeling, 36(1), 89-110.

xxxvii. Inan, G. G., \& Bititci, S. U. (2015). Understanding organizational capabilities and dynamic capabilities in the context of micro enterprises: a research agenda. Procedia-Social and Behavioral Sciences, 210(1), 310319.

xxxviii. Iniguez-Montiel, J. A. (2014). Growth with equity for the development of Mexico: Poverty, inequality, and economic growth (1992-2008). World development, 59(1), 313-326.

xxxix. Islamx, M. M., Khan, M. A., \& Islam, M. M. (2013). Textile industries in Bangladesh and challenges of growth. Research Journal of Engineering Sciences, 2(2), 2278-9472.

xl. Ismail, I. A., \& Abdullah, H. (2012). THE RELATIONSHIP BETWEEN ORGANISATIONAL RESOURCES, CAPABILITIES, SYSTEMS AND COMPETITIVE ADVANTAGE. Asian academy of management Journal, 17, 151-173.

xli. Ismail, I. A., Rose, C. R., Uli, J., \& Abdullah, H. (2012). THE RELATIONSHIP BETWEEN ORGANISATIONAL RESOURCES, CAPABILITIES SYSTEMS AND COMPETITIVE ADVANTAGE. Asian academy of management Journal, 17(1), 151-173.

xlii. Jasra, J., Hunjra, I. A., Rehman, U. A., \& Azam, R. (2011). Determinants of business success of small and medium enterprises. International Journal of Business and Social Science, 2(20), 274-280.

xliii. Javid, M., \& Sharif, F. (2016). Environmental Kuznets curve and financial development in Pakistan. Renewable and Sustainable Energy Reviews, 54(1), 406-414.

xliv. Jones, J., \& Wren, C. (2016). Foreign direct investment and the regional economy. Routledge.

xlv. Kahouli, B., \& Maktouf, S. (2015). Trade creation and diversion effects in the Mediterranean area: Econometric analysis by gravity model. The Journal of International Trade \& Economic Development, 24(1), 76-104

xlvi. Kano, L., \& Verbeke, A. (2018). Family firm internationalization: Heritage assets and the impact of bifurcation bias. Global Strategy Journal, 8(1), 158-183.

xlvii. Kataria, R. J., \& Naveed, A. (2014). Pakistan-China Social and Economic Relations. South Asian Studies, 29(2), 1026-6780.

xlviii. Kato, T., Nunes, B., \& Dey, K. P. (2016). Is keiretsu really a source of competitive advantage for Japanese automotive suppliers? Journal of Manufacturing Technology Management, 27(1), 62-81.

xlix. Kessides, I. N. (2013). Chaos in power: Pakistan's electricity crisis. Energy policy, 55(1), 271-285.

1. Khan, A. T. (2011). Cointegration of international stock markets: An investigation of diversification opportunities. Undergraduate Economic Review, 8(1), 1-7.

li. Kim, J. J., \& Hemmert, M. (2016). What drives the export performance of small and medium-sized subcontracting firms? A study of Korean manufacturers. International Business Review, 25(2), 511-521.

lii. Knight, A. G., \& Liesch, W. P. (2016). Internationalization: From incremental to born global. Journal of World Business, 51(1), 93-102.

liii. Knight, J. (2015). Updated definition of internationalization. Ontario Institute for Studies in Education, International Development Education Centre. Canada: International higher education. Retrieved from https://ejournals.bc.edu/ojs/index.php/ihe/article/viewFi le/7391/6588

liv. Kontinen, T. (2011). Network ties in the international opportunity recognition of family SMEs. International Business Review, 20(4), 440-453.

lv. Kontinen, T., \& Ojala, A. (2010). The internationalization of family businesses: A review of extant research. Journal of Family Business Strategy, 1(2), 97-107.

lvi. Leask, B. (2015). Internationalizing the curriculum. Routledge.

lvii. Lenzen, M., Moran, D., Bhaduri, A., \& Kanemoto, K. (2013). International trade of scarce water. Ecological Economics, 94(1), 78-85.

lviii. Liu, Y., Li, Y., \& Xue, J. (2011). Ownership, strategic orientation and internationalization in emerging markets. Journal of World Business, 46(3), 381-393.

lix. Macchion, L., Moretto, A., Caniato, F., \& Caridi, M. (2015). Production and supply network strategies within the fashion industry. International Journal of Production Economics, 163(1), 173-188.

1x. Martinez-Conesa, I., Soto-Acosta, P., \& Carayannis. (2017). On the path towards open innovation: Assessing the role of knowledge management capability and environmental dynamism in SMEs. Journal of Knowledge Management, 21(3), 553-570.

1xi. Mendenhall, E. M., Osland, J., Bird, A., \& Oddou, G. (2017). Global leadership: Research, practice, and development. Routledge.

1xii. Merino, F., Monreal-Pérez, J., \& Sánchez-Marín, G. (2015). Family SMEs' Internationalization: Disentangling the Influence of Familiness on $\mathrm{S}$ panish Firms' Export Activity. Journal of Small Business Management, 53(4), 1164-1184.

1xiii. Murray, J. Y. (2011). Market orientation and performance of export ventures: the process through marketing capabilities and competitive advantages. Journal of the Academy of Marketing Science, 32(2), 252-269.

lxiv. Murray, Y. J., Gao, Y. G., \& Kotabe, M. (2011). Market orientation and performance of export ventures: the process through marketing capabilities and competitive advantages. Journal of the Academy of Marketing Science, 39(2), 252-269.

lxv. Muzychenko, O., \& Liesch, P. W. (2015). International opportunity identification in the internationalisation of the firm. Journal of World Business, 50(4), 704-717.

1xvi. Ndeisieh, A. E. (2018). Strategies for Success and Sustainability in Small and Medium-Sized Enterprises Beyond the First 5 years. Walden University, 215-216. 


\section{A. Suleman, F. Khalid, I. H. Bokhari}

lxvii. $\quad$ Nunes, P. (2016, 07 30). Organizational Resources. Retrieved from Knoow.net: http://knoow.net/en/economics-

business/management/organizational-resources/

lxviii. Outreville, F. J. (2013). The relationship between insurance and economic development: 85 empirical papers for a review of the literature. Risk Management and Insurance Review, 16(1), 71-122.

1xix. Parida, V., \& Ortqvist, D. (2015). Interactive effects of network capability, ICT capability, and financial slack on technology-based small firm innovation performance. Journal of Small Business Management, 53(1), 278-298.

1xx. Park, C. (2017). A study on effect of entrepreneurship on entrepreneurial intention: Focusing on ICT majors. Asia Pacific Journal of Innovation and Entrepreneurship, 11(2), 159-170.

1xxi. $\quad$ Porter, E. M. (2011). Competitive advantage of nations: creating and sustaining superior performance (Vol. 2). Boston: Simon and Schuster.

1xxii. Rabellotti, R. (2016). External economies and cooperation in industrial districts: a comparison of Italy and Mexico. Springer.

1xxiii. Rahman, M., Uddin, M., \& Lodorfos, G. (2017). Barriers to enter in foreign markets: evidence from SMEs in emerging market. International Marketing Review, 34(1), 68-86.

lxxiv. Ruzzier, M., \& Antoncic, B. (2006). SME internationalization research: past, present, and future Journal of small business and enterprise development, 13(4), 476-497.

1xxv. Saarenketo, S., \& Puumalainen, K. (2004). A global mindset - a prerequisite for successful internationalization? Canadian Journal of Administrative Sciences/Revue Canadienne des Sciences de l'Administration, 21(1), 51-64.

lxxvi. Saebi, T., \& Foss, J. N. (2015). Business models for open innovation: Matching heterogeneous open innovation strategies with business model dimensions. European Management Journal, 33(3), 201-213.

1xxvii. $\quad$ Saeidi, P. S., Sofian, S., Saeidi, P., \& Saeidi, S. (2015) How does corporate social responsibility contribute to firm financial performance? The mediating role of competitive advantage, reputation, and customer satisfaction. Journal of business research, 68(2), 341350 .

1xxviii. Salanova, M., Agut, S., \& Peiro, M. J. (2005). Linking organizational resources and work engagement to employee performance and customer loyalty: the mediation of service climate. Journal of applied Psychology, 90(6), 1217-1218.

lxxix. Salanova, M., Agut, S., \& Peiró, M. J. (2005). Linking organizational resources and work engagement to employee performance and customer loyalty: the mediation of service climate. Journal of applied Psychology, 90(6), 1217-1218.

1xxx. Sanghi, S. (2016). The handbook of competency mapping: understanding, designing and implementing competency models in organizations. SAGE Publications India.

lxxxi. Sanghi, S. (2016). The handbook of competency mapping: understanding, designing and implementing competency models in organizations. New Delhi: SAGE Publications India.

1xxxii. Schuerholz-Lehr, S. (2007). Teaching for global literacy in higher education: How prepared are the educators? Journal of Studies in International Education, 11(2), 180-204.

1xxxiii. Senik, Z. C., Scott-Ladd, B., Entrekin, L., \& Adham, K. A. (2011). Networking and internationalization of SMEs
Volume VIII, Issue II, 2019, 10-15

in emerging economies. Journal of International Entrepreneurship, 9(4), 259-281.

lxxxiv. Shah, H. T., Javed, S., \& Syed, S. (2013). Internationalization of SMES in Pakistan: A Brief Theoretical Overview of Controlling Factors. Journal of Managerial Sciences, 7(2), 214-230.

lxxxv. Shah, H. T., Javed, S., \& Syed, S. (2013). Internationalization of SMES in Pakistan: A Brief Theoretical Overview of Controlling Factors. Journal of Managerial Sciences, 7(2), 214-230.

1xxxvi. Shaikh, F., Ji, Q., \& Fan, Y. (2015). The diagnosis of an electricity crisis and alternative energy development in Pakistan. Renewable and Sustainable Energy Reviews, 52(1), 1172-1185.

1xxxvii. Shakeel, R. S., Takala, J., \& Shakeel, W. (2016). Renewable energy sources in power generation in Pakistan. Renewable and Sustainable Energy Reviews, 64(1), 421-434.

1xxxviii. Sial, S. (2014). The China-Pakistan Economic Corridor: an assessment of potential threats and constraints. Conflict and Peace Studies, 6(2), 1-24.

1xxxix. Smyth, S. J., Kerr, A. W., \& Phillips, W. P. (2015). Global economic, environmental and health benefits from GM crop adoption. Global food security, 7(1), 2429.

xc. Surugiu, R. M., \& Surugiu, C. (2015). International trade, globalization and economic interdependence between European countries: Implications for businesses and marketing framework. Procedia Economics and Finance, 32(1), 131-138.

xci. Szymanski, S. (2016). Professional Asian football leagues and the global market. Asian Economic Policy Review, 11(1), 16-38.

xcii. Teece, J. D. (2007). Explicating dynamic capabilities: the nature and microfoundations of (sustainable) enterprise performance. Strategic management journal, 28(13), 1319-1350.

xciii. Teece, J. D., Pisano, G., \& Shuen, A. (1997). Dynamic capabilities and strategic management. Strategic management journal, 18(7), 509-533.

xciv. Teichler, U. (2004). The changing debate on internationalisation of higher education. Higher education, 48(1), 5-26.

xcv. Tiefenbrum, S. (2013). US Foreign Trade Zones, TaxFree Trade Zones of the World, and Their Impact on the US Economy. Journal of International Business and Law, 12(2), 1-149.

xcvi. Wübbeke, J. (2013). Rare earth elements in China: Policies and narratives of reinventing an industry. Resources Policy, 38(3), 384-394.

xcvii. Yeeles, A., \& Akporiaye, A. (2016). Risk and resilience in the Nigerian oil sector: The economic effects of pipeline sabotage and theft. Energy Policy, 88(1), 187196.

xcviii. Zheng, N., Wei, Y., \& Yang, J. (2016). In search of strategic assets through cross-border merger and acquisitions: Evidence from Chinese multinational enterprises in developed economies. ,. International Business Review, 25(1), 177-186.

xcix. Zhou, L., \& Wu, A. (2014). Earliness of internationalization and performance outcomes: Exploring the moderating effects of venture age and international commitment. Journal of World Business, 49(1), 132-142. 